\title{
Analisis Peak Ground Acceleration (PGA) dan Intensitas Gempabumi berdasarkan Data Gempabumi Terasa Tahun 1981 - 2014 di Kabupaten Bantul Yogyakarta
}

\author{
Nugroho Budi Wibowo ${ }^{1}$, dan Juwita Nur Sembri ${ }^{1}$ \\ ${ }^{1}$ Badan Meteorologi Klimatologi dan Geofisika, Stasiun Geofisika Yogyakarta \\ Jl. Wates km 8, Jitengan, Balecatur, Gamping, Sleman, D. I. Yogyakarta, Telp (0274) 6498383 \\ nugrohobudiwibowo@gmail.com
}

Received 01-01-2016, Revised 29-02-2016, Accepted 16-03-2016, Published 20-04-2016

\section{ABSTRAK}

Sejarah kegempaan Jawa antara tahun 1981 hingga 2014 mencatat bahwa Daerah Istimewa Yogyakarta telah dilanda gempabumi merusak sebanyak 4 kali dan ratusan gempabumi terasa. Penelitian ini bertujuan mengkaji zona percepatan tanah maksimum (PGA) dan intensitas gempabumi berdasarkan data historis kejadian gempabumi dari tahun 1981-2014. Perhitungan percepatan tanah maksimum menggunakan persamaan Kanai dan intensitas gempabumi menggunakan persamaan Wald. Penelitian ini dilakukan dengan menggunakan 231 data pengukuran mikrotremor di sekitar Kabupaten Bantul yang berasal dari BMKG serta 147 data gempabumi merusak dan terasa dari BMKG. Hasil penelitiaan menunjukkan nilai PGA di Kabupaten Bantul bervariasi dari 57,7-412,7 gal. Zonasi PGA di Kabupaten Bantul dibagi menjadi tiga zona, yaitu zona pertama dengan nilai percepatan 57,7-91 gal, zona kedua dengan nilai percepatan 92-179 gal dan zona ketiga dengan nilai percepatan >180 gal. Sedangkan berdasarkan intensitas gempa bumi, Kabupaten Bantul memiliki potensi kerusakan dalam intensitas V-VII MMI.

Kata kunci: Percepatan Tanah Maksimum (PGA), intensitas gempabumi, mikrotremor, periode dominan, Kanai, Wald.

\section{ABSTRACT}

Seismic historical record in Java period of 1981-2014 recorded that the Special Region of Yogyakarta was hit by damaging earthquake 4 times and hundreds of small earthquakes felt. This research was aimed to assess the peak ground acceleration (PGA) zone and the earthquake intensity based on historical data of earthquake occurrence in 1981-2014. Peak Ground Acceleration was calculated using Kanai equation and earthquake intensity using Wald equation. This research was conducted by using 231 microtremor data in Bantul District that derived from BMKG and also 147 data of damaging earthquake and small earthquake felt from BMKG. The result of this study represent peak ground acceleration value in Bantul District which was varied from 57.7-412.7 gal. Peak Ground Acceleration Zonation of Bantul District was diveded by 3 zones; first zone with PGA value 57.7-91 gal, the second zone with PGA value 92-179 gal and the third zone with PGA value higher than 180 gal. While based on earthquake intensity, Bantul District has damage potential of V-VII MMI in intensity scale.

Keyword: Peak Ground Acceleration (PGA), Earthquake Intensity, Microtremor, Kanai, Wald.

\section{PENDAHULUAN}

Kepulauan Indonesia terletak pada pertemuan tiga lempeng tektonik utama, yaitu lempeng Indo-Australia di bagian Selatan dan Barat, lempeng Eurasia di bagian Utara, dan lempeng Pasifik di bagian Timur ${ }^{[3]}$. Kondisi ini membuat Kepulauan Indonesia memiliki resiko 
terhadap becana gempabumi. Daerah Istimewa Yogyakarta yang berada di Utara jalur pertemuan lempeng Indo-Austaralia dan Eurasia memiliki resiko gempabumi akibat jalur subduksi kedua lempeng tersebut. Dari catatan sejarah kegempaan Jawa antara tahun 1821 hingga 2009, Daerah Istimewa Yogyakarta telah dilanda gempabumi merusak sebanyak 4 kali dan ratusan gempabumi terasa ${ }^{[1]}$. Gempabumi 2006, merupakan gempabumi merusak dan menimbulkan korban jiwa yang cukup signifikan khususnya di Kabupaten Bantul. Penelitian ini bertujuan mengkaji zona percepatan tanah maksimum dan intensitas gempabumi berdasarkan data historis kejadian gempabumi dari tahun 1981-2014. Perhitungan percepatan tanah maksimum menggunakan persamaan Kanai dengan memperhitungkan faktor periode dominan tanah di Kabupaten Bantul.

\section{Periode dominan}

Penentuan periode dominan diperoleh dari persamaan :

$$
T_{g}=\frac{1}{f_{o}}
$$

$T_{g}$ merupakan periode dominan (s) dan $f_{o}$ merupakan frekuensi dominan $(\mathrm{Hz})$

\section{Frekuensi dominan}

Frekuensi dominan diperoleh dari pengukuran mikrotremor dengan menggunakan metode HVSR. Persamaan HVSR untuk getaran terukur di permukaan dinyatakan :

$$
\boldsymbol{H V S R}=\frac{\sqrt{\left(A_{(U-S)}(f)\right)^{2}+\left(A_{(B-T)}(f)\right)^{2}}}{\left(A_{(V)}(f)\right)}
$$

HVSR = Horizontal to Vertical Ratio

$A_{(U-S)}(f)=$ Nilai Amplitudo spektrum frekuensi komponen Utara-Selatan

$A_{(B-T)}(f)=$ Nilai Amplitudo spektrum frekuensi komponen Barat-Timur

$\left(A_{(V)}(f)\right)=$ Nilai Amplitudo spektrum frekuensi komponen Vertikal

\section{Percepatan tanah maksimum (PGA)}

Penentuan model percepatan tanah ini menggunakan metode Kanai (1966) ${ }^{[2]}$, yakni:

$$
\alpha=\frac{5}{\sqrt{T_{g}}} 10^{0.61 M-\left(1.66+\frac{3.6}{R}\right) \log R+0.67-\frac{1.83}{R}}
$$

Dimana, $\alpha$ (PGA dalam gal), Tg (periode dominan tanah dalam second), M (Magnitude dalam Skala Richter) dan R (jarak hypocenter dalam $\mathrm{km}$ ).

\section{Intensitas gempabumi (IмM)}

Persamaan intensitas gempabumi berdasarkan persamaan Wald ${ }^{[3]}$.

$$
I M M=3,66 \log \alpha-1,66
$$

$I_{M M}=$ Intensitas gempa menurut skala MMI dan $\alpha=$ percepatan tanah maksimum (gal)

\section{METODE PENELITIAN}

Diagram alir penelitian ditunjukkan oleh Gambar 3. Penelitian ini dilakukan dengan menggunakan 231 data pengukuran mikrotremor di sekitar Kabupaten Bantul yang berasal dari BMKG dan parameter gempabumi dari katalog BMKG (Gambar 1). Katalog yang 
digunakan pada penelitian ini yaitu Katalog Gempabumi Signifikan dan Merusak Tahun 1821-2009 dari BMKG Pusat dengan sumber data dari E.I (earthquake in Indonesia), E.R (Earthquake Report),G.N (Geophyscal Notes), N.T (Natuurkunding Tijdschrift voor Nederlandsch-Indie),S.I (Seismology in Indonesia), USGS (United State Geological Survey) dan BMKG (Badan Meteorologi Klimatologi dan Geofisika). Selain itu, katalog gempabumi terasa di Kabupaten Bantul tahun 2005-2014 dari Stasiun Geofisika Yogyakarta. Pengukuran mikrotremor menggunakan TDS-303 portabel seismograph yang ditunjukkan oleh Gambar 2, kompas geologi, GPS, dan Laptop. Standar operasional pengukuran alat tersebut berdasarkan pada SESAME European research project ${ }^{[5]}$ dengan durasi pengukuran 30 menit untuk setiap titiknya. Pengolahan data menggunakan software NetRec, DataPro, Geopsy, dan Arc Gis 9.2. Metode pengolahan data mikrotremor menggunakan metode HVSR (Horizontal to Vertical Ratio) untuk menghasilkan variabel utama berupa data frekuensi dominan $(f o)$ dan faktor amplifikasi $(A)$. Data periode dominan tanah diperoleh dari Persamaan 1 dan digunakan untuk menentukan percepatan tanah maksimum pada Persamaan 3 beserta parameter gempabumi dari katalog BMKG. Nilai percepatan tanah maksimum dikonversi menjadi nilai intensitas gempabumi berdasarkan Persamaan 4.

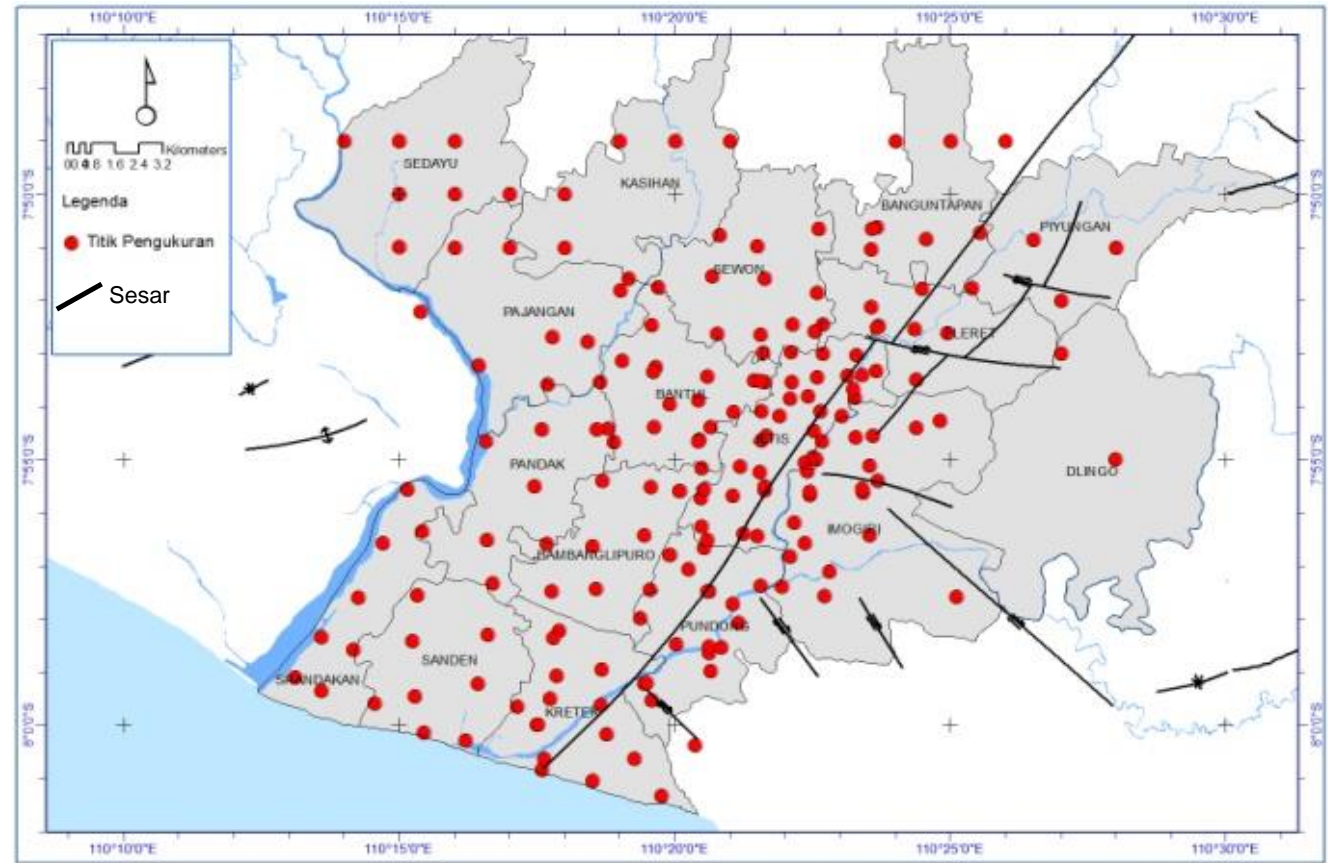

Gambar 1. (Colour online) Peta titik lokasi pengukuran mikrotremor

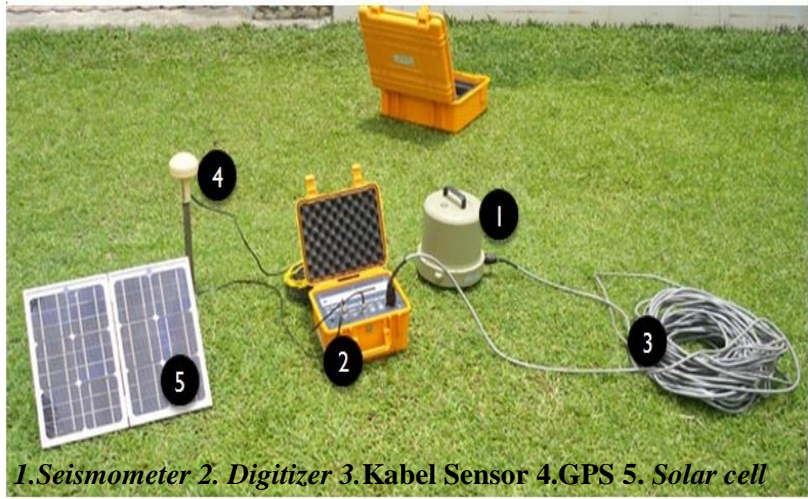

Gambar 2. (Colour online)Portabel seismograph ${ }^{[6]}$ 


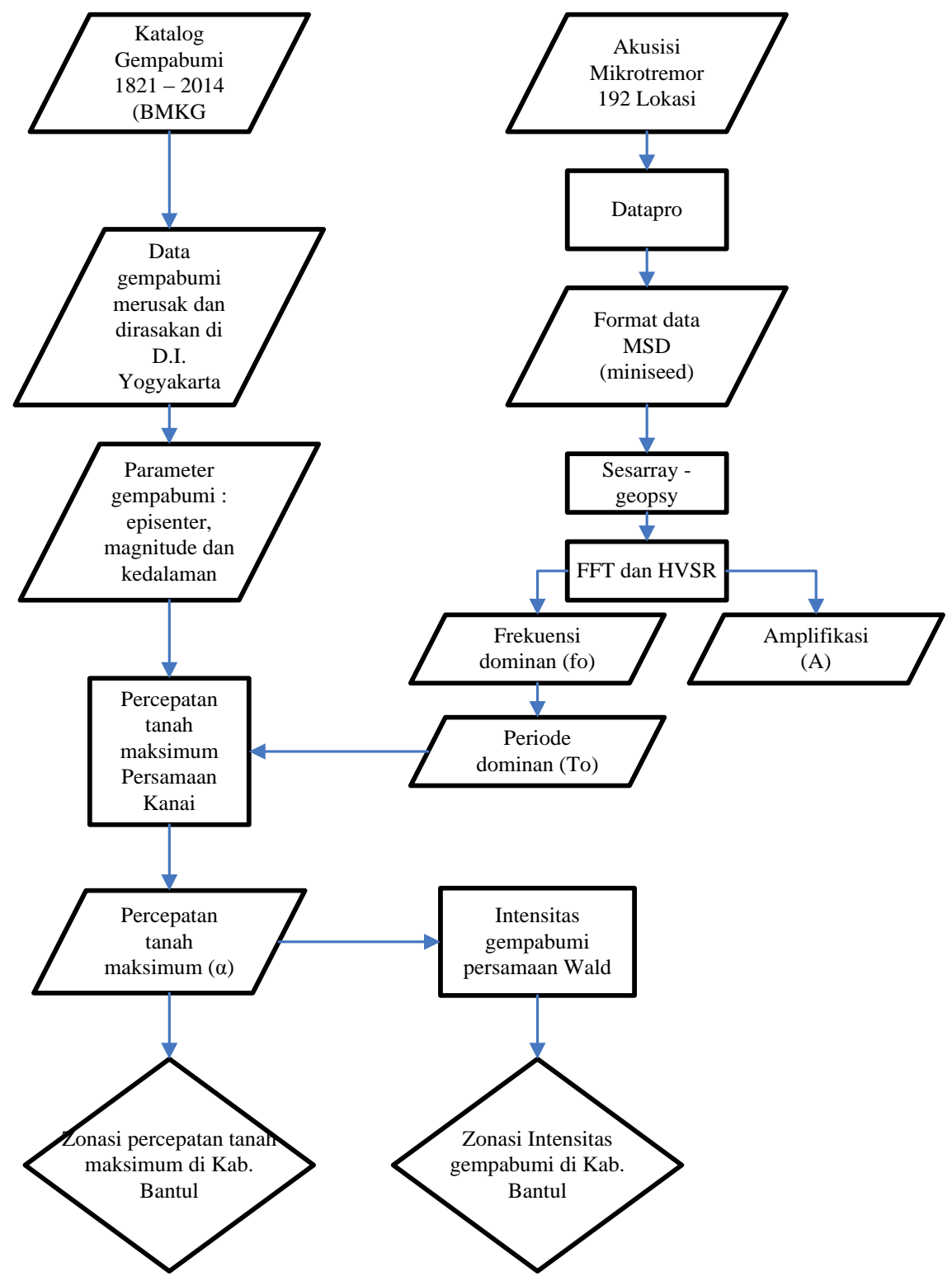

Gambar 3. Diagram alir penelitian

\section{HASIL DAN PEMBAHASAN}

\section{Gempabumi Merusak dan Dirasakan di Kab. Bantul}

Sejarah mencatat empat kali gempabumi signifikan dan merusak di wilayah Yogyakarta yang tercatat pada katalog gempabumi signifikan dan merusakan tahun 1821-2009 dan lebih dari 100 data gempabumi terasa berdasarkan data gempabumi terasa dari Stasiun Geofisika Yogyakarta. Gempabumi signifikan dan merusak terjadi pada tahun 1943, 13 Maret 1981 dengan intensitas di Yogyakarta VII MMI dengan dampak yang ditimbulkannya yaitu dinding Hotel Ambarukmo retak. Pada tanggal 25 Mei 2001dengan magnitude 6.3 SR kedalaman $143 \mathrm{~km}$ dan intensitas di Yogyakarta V MMI serta terdapat kerusakan ringan di Yogyakarta. Pada tanggal 26 Mei 2006 dengan magnitude 5,9 SR kedalman $33 \mathrm{~km}$ dan intensitas di Bantul Klaten IX MMI, Sleman dan Kota Yogyakarta VII MMI. Gempabumi ini menimbulkan kerusakan $>100.000$ rumah rusak. Gambar 4 menunjukkan distribusi episenter gempabumi signifikan dan merusak yang pernah terjadi di wilayah Yogyakarta. 


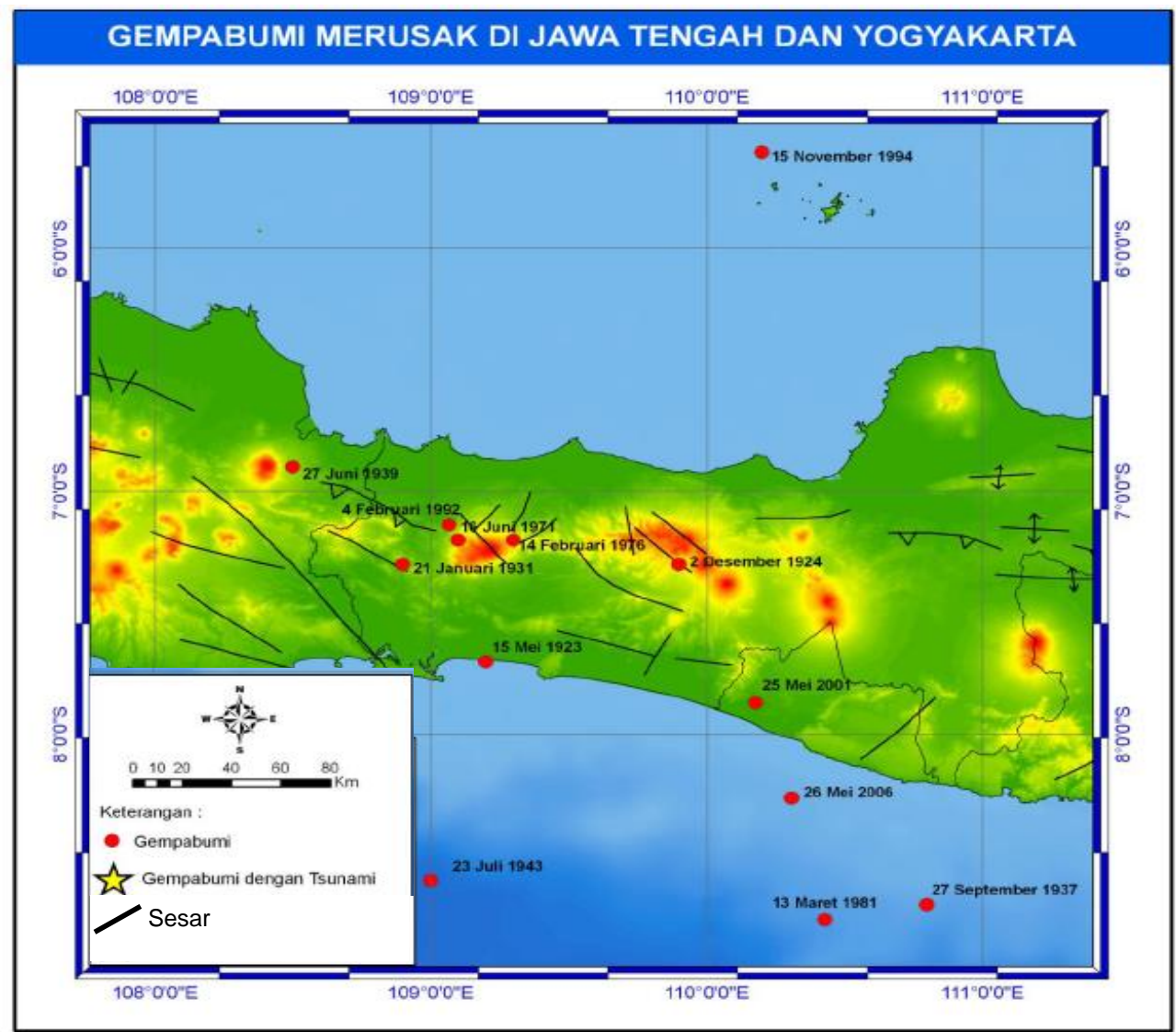

Gambar 4. (Colour online) Peta Gempabumi Merusak di Jawa Tengah dan D.I Yogyakarta

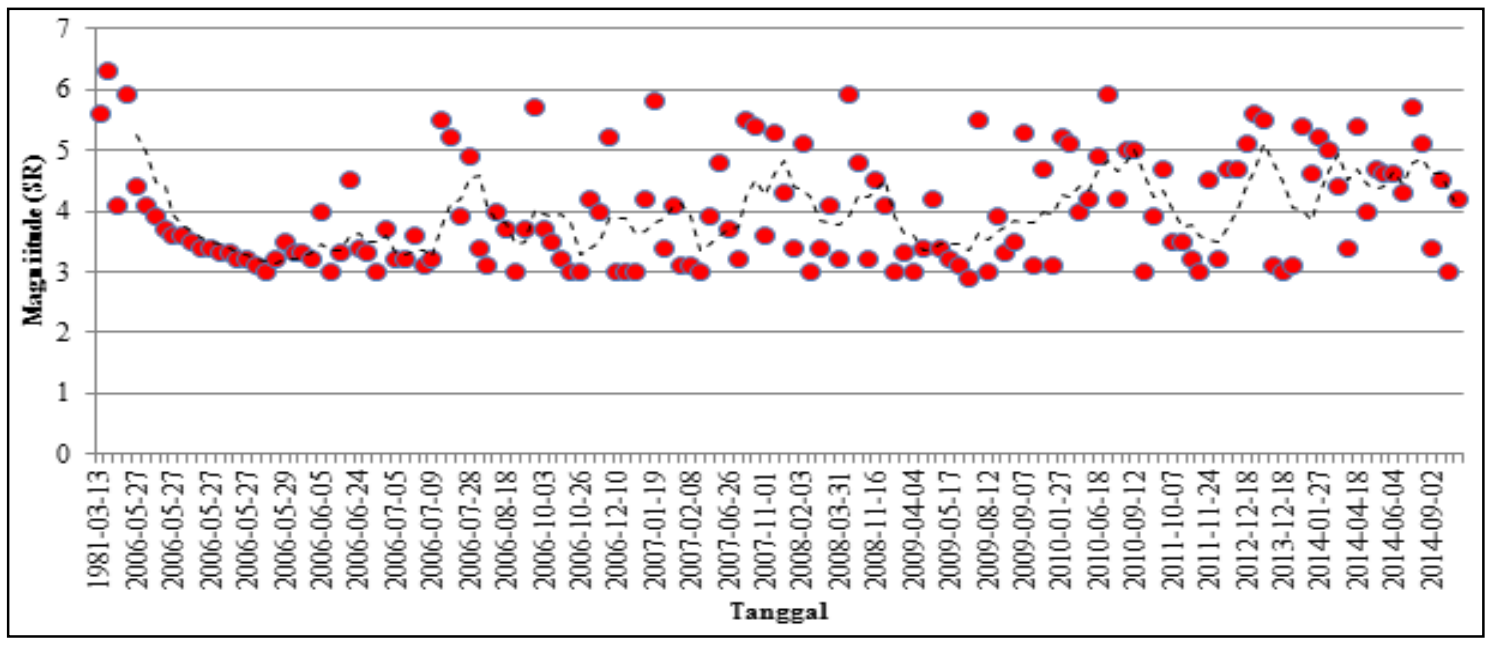

Gambar 5. (Colour online) Grafik moving average magnitude gempabumi terasa di Kabupaten Bantul

Penelitian ini selain menggunakan data gempabumi signifikan dan merusak juga menggunakan input data gempabumi terasa di wilayah Yogyakarta khususnya Kabupaten Bantul. Sehingga berdasarkan katalog, data yang digunakan, data gempa dari tahun 19812014. Jumlah data gempabumi yang digunakan sebanyak 147 data gempabumi. Tren magnitude gempabumi dirasakan di Kabupaten Bantul menunjukkan pola yang naik turun, yang artinya gempabumi terasa di Kabupaten Bantul tidak selalu diakibatkan oleh gempabumi dengan magnitude $>5 \mathrm{SR}$. Namun, gempabumi dengan magnitude $<5 \mathrm{SR}$ dan kedalaman dangkal dapat mengakibatkan gempabumi terasa. Gambar 5, menunjukkan grafik moving average kejadian gempabumi terasa di Kabupaten Bantul. 


\section{Percepatan Tanah Maksimum di Kabupaten Bantul}

Nilai percepatan tanah maksimum dihasilkan dengan pendekatan Kanai berdasarkan 147 data gempabumi terasa dan 231 data periode dominan hasil pengukuran mikrotremor. Variasai nilai periode dominan tanah bervariasi dari 0,1-2,0 s. Nilai ini menunjukkan bahwa Kab. Bantul tersusun atas material tersier hingga sedimentasi berupa dataran aluvial. Nilai periode dominan memliki fungsi pengontrol pada metode Kanai selain parameter gempabumi. Sehingga besarnya percepatan tanah akan dipengaruhi faktor geologi setempat yang terwakilkan oleh nilai periode dominan tanah.

Nilai percepatan tanah maksimum di Kabupaten Bantul bervariasi dari 57,7-412,7 gal seperti ditunjukan pada Gambar 7.

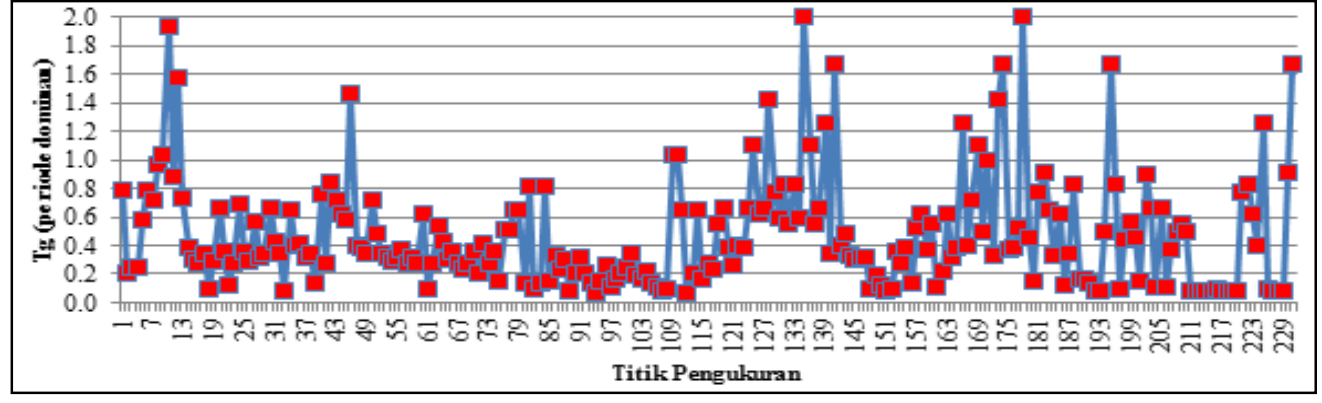

Gambar 6. (Colour online) Nilai Tg pada Titik Pengukuran di Kab. Bantul

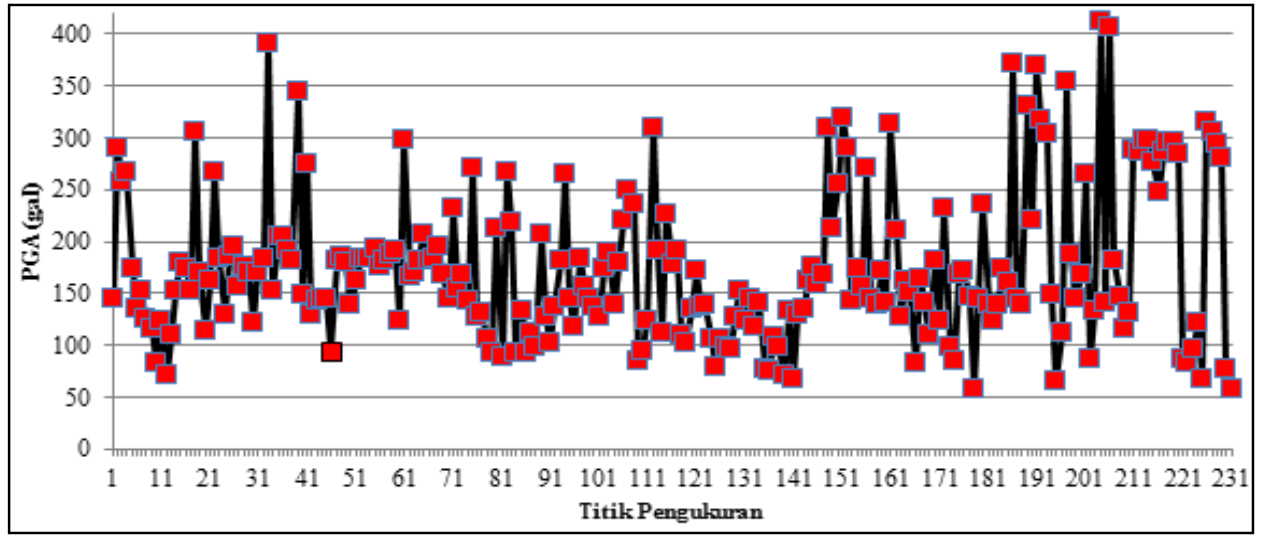

Gambar 7. (Colour online) Grafik PGA di Kab. Bantul pada setiap titik pengukuran

Zonasi percepatan tanah maksimum di Kabupaten Bantul dibagi menjadi tiga zona, yaitu zona pertama dengan nilai percepatan 57,7 -91 gal, zona kedua dengan nilai percepatan 92179 gal dan zona ketiga dengan nilai percepatan >180 gal. Gambar 7 menunjukkan zonasi $P G A$ di Kab. Bantul, dengan distribusi $P G A$ lebih dari 180 gal terdapat di wilayah Barat dan Timur Kab. Bantul. Zona tersebut mencakup Kecamatan Sedayu, Pajangan, Pandak Kasihan, Bantul dan sebagian kecil Kec. Bambanglipuro di wilayah Barat. Sedangkan di wilayah Timur antara lain Kec. Piyungan, Dlingo, Pleret, Imogiri, Pundong dan Kretek. Zona dengan PGA antara 92-179 gal terdapat di Kec. Sewon, Pleret, Jetis, Bantul, Bambanglipuro, Pundong, Kretek, Sanden dan Srandakan. Zona dengan PGA antara 57.791 gal terdapat pada Kec. Banguntapan. Semakin besar nilai $P G A$ maka potensi terjadi kerusakan, wilayah pada zona $>180$ gal memiliki potensi kerusakan ringan untuk bangunan dengan konstruksi baik. 


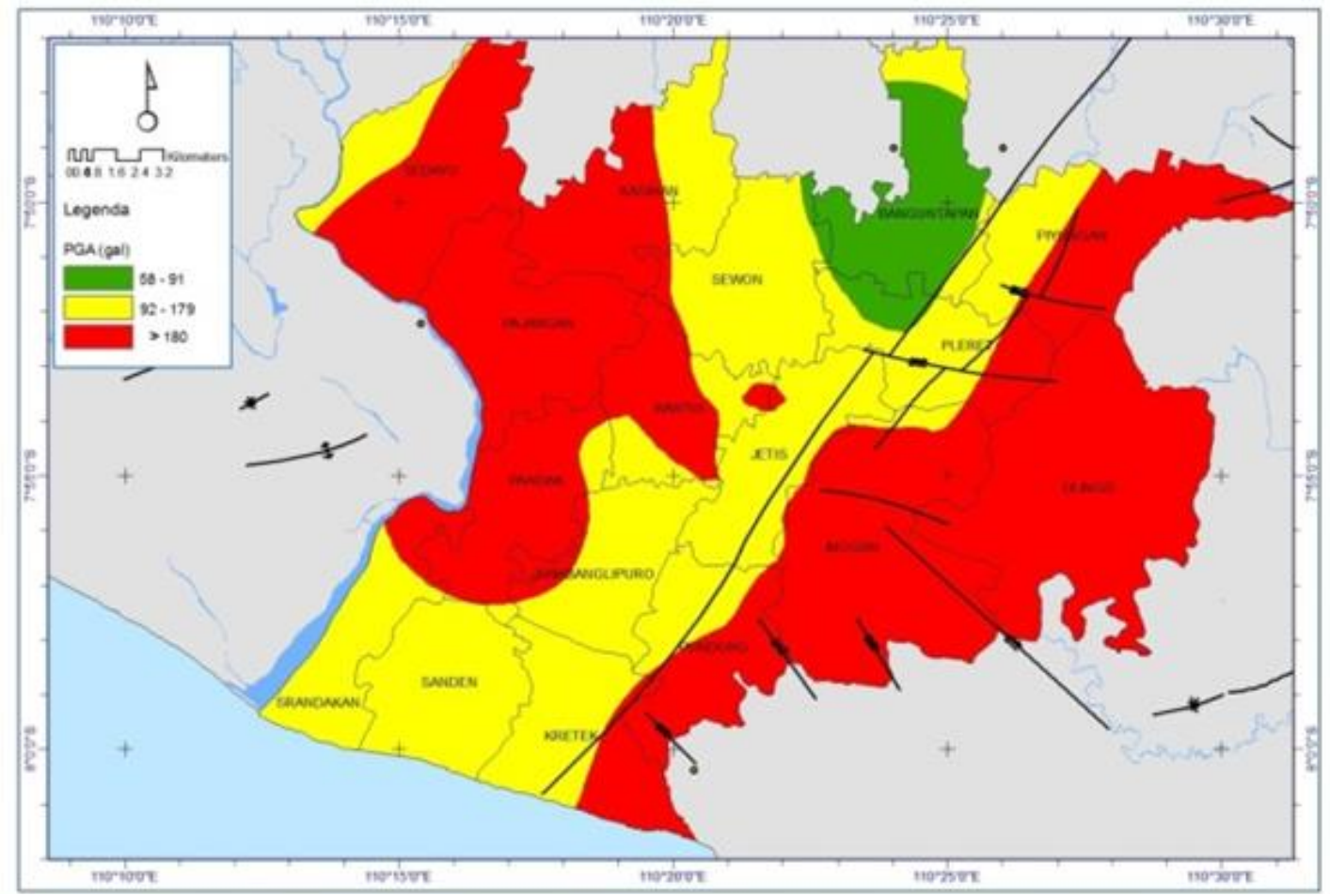

Gambar 8. (Colour online) Zonasi PGA dengan metode Kanai di Kab. Bantul berdasarkan data gempa 19812014

\section{Intensitas Gempabumi di Kabupaten Bantul}

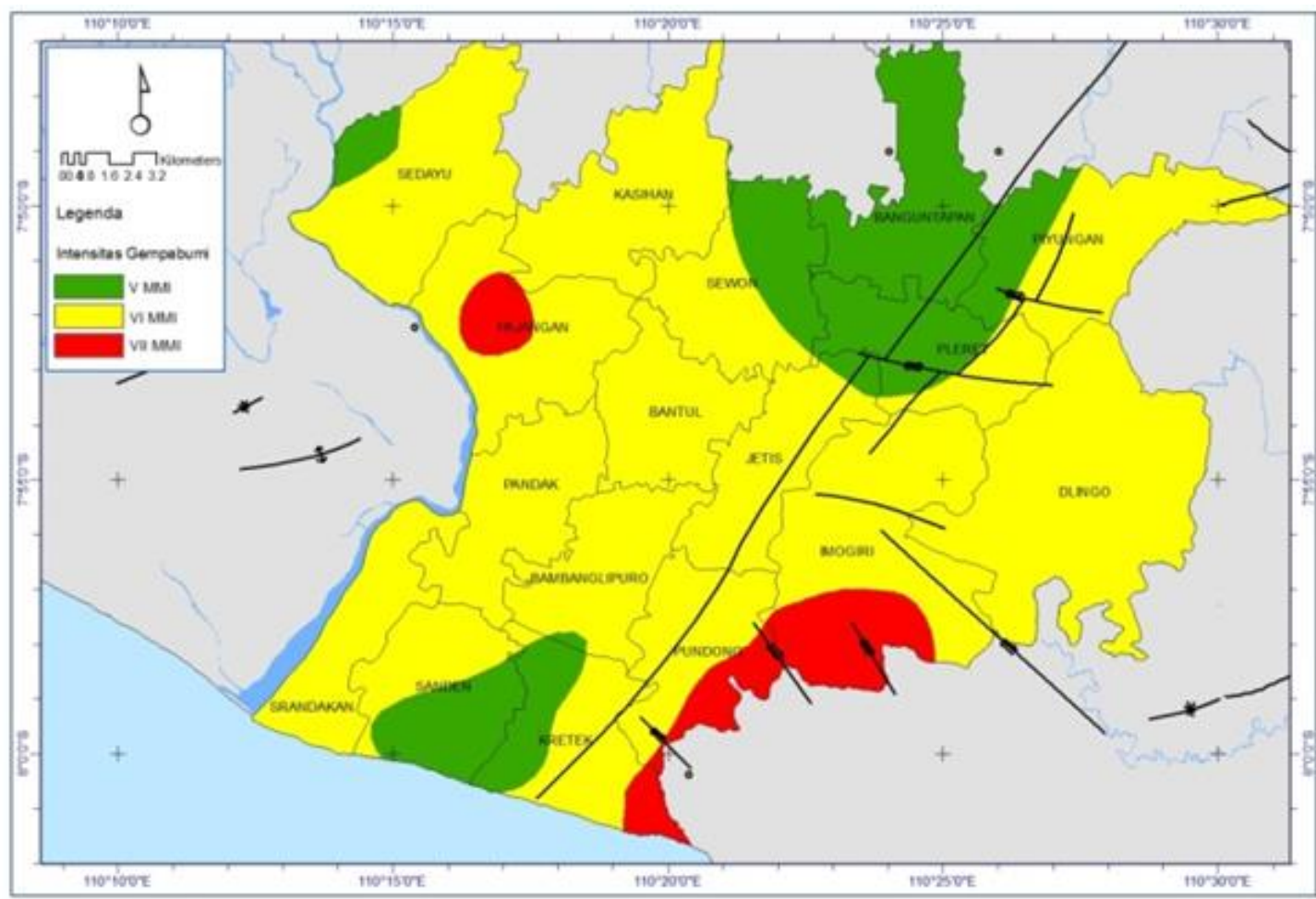

Gambar 9. (Colour online) Zonasi Intensitas dengan metode Wald di Kab. Bantul berdasarkan data gempa 1981-2014

Intensitas gempabumi dapat merepresentasikan tingkat kerusakan yang terjadi sebagai dampak adanya gempabumi di suatu wilayah. Perhitungan intensitas gempabumi pada 
penelitian ini menggunakan persamaan Wald dengan memperhitungkan nilai $P G A$. Skala intensitas gempabumi dari I MMI hingga XII MMI. Semakin tinggi skala intensitas, maka semakin besar kerusakan yang terjadi akibat gempabumi. Hasil perhitungan intensitas menunjukkan bahwa Kab. Bantul memiliki potensi kerusakan dalam intensitas V-VII MMI. Kecamatan yang berada pada zona V MMI antara lain Kec. Banguntapan, Sewon, Piyungan, Sanden, Kretek dan sebagian kecil Kec. Sedayu. Kecamatan yang berada pada zona VI MMI antara lain Kec. Sedayu, Kasihan, Sewon, Pajangan, Bantul, Pandak, Srandakan, Bambanglipuro, Sanden, Kretek, Pundong, Imogiri, Jetis, Dlingo, Piyungan dan Pleret. Sedangkan kecamatan pada zona VII MMI antara lain Kec. Imogiri, Pundong, Kretek dan Pajangan. Gambar 8 menunjukkan zonasi intensitas gempabumi di Kab. Bantul berdasarkan data gempabumi terasa 1981-2014.

\section{KESIMPULAN}

Nilai percepatan tanah maksimum di Kabupaten Bantul berdasarkan gempabumi 19812014 bervariasi dari 57,7-412,7 gal. Zonasi percepatan tanah maksimum di Kabupaten Bantul dibagi menjadi tiga zona, yaitu zona pertama dengan nilai percepatan 57,7-91 gal, zona kedua dengan nilai percepatan 92-179 gal dan zona ketiga dengan nilai percepatan $>180$ gal.

Kabupaten Bantul memiliki potensi kerusakan dalam intensitas V-VII MMI. Kecamatan yang berada pada zona V MMI antara lain Kec. Banguntapan, Sewon, Piyungan, Sanden, Kretek dan sebagian kecil Kec. Sedayu. Kecamatan yang berada pada zona VI MMI antara lain Kec. Sedayu, Kasihan, Sewon, Pajangan, Bantul, Pandak, Srandakan, Bambanglipuro, Sanden, Kretek, Pundong, Imogiri, Jetis, Dlingo, Piyungan dan Pleret. Sedangkan kecamatan pada zona VII MMI antara lain Kec. Imogiri, Pundong, Kretek dan Pajangan.

\section{DAFTAR PUSTAKA}

1. BMKG. 2010. Katalog Gempabumi Signifikan dan Merusak 1821-2009. Sub Bidang Mitigasi Gempabumi, Jakarta.

2. Douglas, J. 2004. Ground motion estimation equations 1964-2003. London: Imperial Colleage.

3. Ibrahim, Gunawan, dan Subardjo. 2005. Pengetahuan Seismologi. Jakarta: Badan Meteorologi dan Geofisika.

4. Kirbani, dkk. 2006. Percepatan Getaran Tanah Maksimum Daerah Istimewa Yogyakarta 1943-2006. Jurnal Geofisika 19, Vol.

5. SESAME. 2004. Guidelines for the implementation of the $h / v$ spectral ratio technique on ambient vibrations measurements, processing and interpretation.

6. Wibowo, N. B. 2015. Spatial Analysis of Surface Aquifer Thickness Based Frequency predominant in Bantul District. Indonesian Journal of Applied Physics, Vol.5, No.1, Hal. 63-71. 